\title{
Kelas "Tommoane Masayang" meningkatkan pengetahuan dan keterampilan suami tentang kesehatan ibu dan anak
}

\author{
Immawanti Immawanti ${ }^{1^{*}}$, Munadiah Wahyuddin ${ }^{2}$, Raehan $^{3}$, Nur Anita $^{4}$ \\ ${ }^{1,2.3 .4}$ Program Studi IImu Keperawatan, STIKES Marendeng Majene, Indonesia \\ * Coresponding Author: immawanti.ch@gmail.com
}

\begin{abstract}
Abstrak
Pendahuluan: Salah satu tujuan dari program kesehatan ibu dan anak adalah peningkatan kemandirian keluarga dalam memelihara kesehatan ibu dan anak. Tujuan penelitian ini untuk mengetahui pengaruh kelas "Tommoane Masayang" terhadap pengetahuan dan keterampilan para suami mengenai kesehatan ibu dan anak. Metode: Desain penelitian yang digunakan adalah quasi eksperiment, one group pre dan post test desain. Sampel yang digunakan adalah para suami ibu hamil dengan usia kehamilan $28-40$ minggu. Instrument penelitian yang digunakan yaitu kuesioner dan media KIE yaitu buku KIA, leafleat, dan boneka bayi. Hasil: Hasil penelitian menunjukkan bahwa $P$ value $=0,031$ dan 0,001, < $\alpha$ 0,05. Simpulan: Ada pengaruh kelas "Tommoane Masayang" terhadap peningkatan pengetahuan dan keterampilan suami tentang kesehatan ibu dan anak. Partisipasi suami merupakan bagian dari tanggujawab sebagai salah satu bentuk dari upaya pemeliharaan kesehatan reproduksi yaitu dengan keterlibatan suami dalam peningkatan pengetahuan dan keterampilan tentang kesehatan ibu dan anak. Keterlibatan suami selama masa kehamilan istri sampai persalinan, dibutuhkan dukungan dari petugas kesehatan.
\end{abstract}

Kata kunci: Kesehatan ibu dan anak; kehamilan; keterampilan; pengetahuan; tommoane masayang

"Tommoane Masayang" class improved husband's knowledge and skills about maternal and child health

\begin{abstract}
Introduction: One of the goals of the maternal and child health program is to increase family independence in maintaining the health of mothers and children. The purpose of this study was to determine the effect of the "Tommoane Masayang" class on the knowledge and skills of husbands regarding maternal and child health. Methods: The research design used was a quasi experiment, one group pre and post test design. The samples used were husbands of pregnant women with a gestational age of 28-40 weeks. The research instruments used were questionnaires and IEC media, namely the KIA book, leafleat, and baby dolls. Results: The results of this study indicate that $P$ value $=0,031$ and 0,001, $<\alpha 0,05$. Conclusions: There is an effect of the "Tommoane Masayang" class on increasing husbands' knowledge and skills about maternal and child health. Husband's participation is the responsibility of men, one form of efforts to maintain reproductive health, namely the involvement of husbands in increasing knowledge and skills related to maternal and child health. In an effort to increase the husband's knowledge and skills in the husband's involvement during the wife's pregnancy and delivery, support from health workers is needed.
\end{abstract}

Keywords : Maternal and child health; pregnancy; skills; knowledge; tommoane masayang

How to Cite: Immawanti, I., Wahyuddin, M.R., \& Anita, N. (2020). Kelas "Tommoane Masayang" meningkatkan pengetahuan dan keterampilan suami tentang kesehatan ibu dan anak. NURSCOPE: Jurnal Penelitian dan Pemikiran IImiah Keperawatan, 6 (2), 81-87 


\section{PENDAHULUAN}

Pembangunan kesehatan di Indonesia masih menjadi prioritas dalam upaya peningkatan derajat kesehatan ibu dan anak. Salah satu tujuan dari program kesehatan ibu dan anak, yaitu peningkatan kemandirian keluarga dalam memelihara kesehatan ibu dan anak. Kesehatan Ibu dan Anak (KIA) merupakan kelompok yang paling rentan terhadap berbagai masalah kesehatan dan seringkali berakhir dengan kematian. Kesehatan ibu hamil merupakan aspek penting untuk diperhatikan karena sepanjang kehamilan dapat terjadi komplikasi yang berisiko mengancam kesehatan ibu dan berdampak pada tingginya Angka Kematian Ibu (AKI) (Kemkes RI, 2017).

Angka Kematian Ibu merupakan indikator derajat kesehatan di suatu wilayah. Indonesia, menduduki posisi ketiga AKI tertinggi tahun 2017 dengan 177 per 100.000 kelahiran hidup (The World Bank, 2019), sedangkan target yang harus dicapai berdasarkan SDGs pada tahun 2030 adalah 70 per 100.000 kelahiran hidup. Faktor penyebab kematian ibu dikelompokkan menjadi penyebab langsung dan penyebab tidak langsung. Penyebab langsung, yaitu faktor yang berhubungan dengan komplikasi kehamilan, persalinan dan nifas seperti pre eklamsia atau eklamsia, infeksi, persalinan macet dan abortus. Sedangkan penyebab tidak langsung seperti kondisi empat terlalu (terlalu muda, terlalu tua, terlalu sering melahirkan dan terlalu dekat jarak kelahiran). Faktor lainnya seperti sosial budaya, pemanfaatan fasilitas pelayanan kesehatan, sosial ekonomi, kesiapan mental ibu, serta dukungan suami dan keluarga dalam persiapan dan perencanaan persalinan (Profil Kesehatan Indonesia, 2018).

Kematian ibu merupakan hal yang dapat dicegah, dihindari dan membutuhkan perhatian dari masyarakat (Gholamreza, Mohsen, Raheleh, Somayeh, Mazaheri, 2013). Salah upaya dalam menurunkan AKI, yaitu dengan peran serta masyarakat melalui kegiatan konseling, informasi dan edukasi (KIE). KIE berupa penyuluhan tentang kesehatan ibu kepada berbagai sasaran termasuk ibu hamil, suami, dan mertua dan memanfaatkan media cetak dan elektronik untuk kampanye kesehatan ibu (Kemkes RI, 2017). Penyuluhan dalam bentuk KIE diberikan berulang kali sejak masa kehamilan agar terjadi peningkatan pengetahuan dan perubahan perilaku. Penyuluhan yang diberikan berupa konsultasi perorangan pada saat ibu datang melakukan pemeriksaan kehamilan, namun dalam pelaksanaan kegiatan tersebut masih memiliki kelemahan di mana pengetahuan yang diperoleh terbatas pada masalah kesehatan ibu dan hanya ibu yang mendapatkan informasi tersebut.

Berdasarkan survei yang dilakukan pada program KIA di Puskesmas Banggae 1 dan Puskesmas Totoli, telah melaksanakan kelas ibu hamil, namun kegiatan tersebut masih dirasakan kurang berdampak terhadap kesiapan dan perencanaan ibu dalam menghadapi persalinan. Oleh karena itu, melalui kegiatan pendidikan dalam bentuk tatap muka yang diikuti oleh para suami. Kelas "Tommoane Masayang" diharapkan para suami mampu memahami kesehatan ibu hamil, komplikasi kehamilan, mempersiapkan dan mendampingi proses persalinan dan mampu mengambil keputusan yang tepat terhadap masalah yang dialami ibu selama kehamilan hingga menjelang persalinan. Berdasarkan fenomena dan masalah tersebut, maka dirumuskan masalah apakah efek kelas "Tommoane Masayang" terhadap pengetahuan dan keterampilan para suami mengenai kesehatan ibu dan anak?

\section{METODE}

Desain penelitian yang digunakan adalah quasi eksperiment, one group pre dan post test desain. Pengukuran pada penelitian ini dilakukan sebanyak 2 kali, yaitu sebelum diberikan perlakuan dan satu kali pengukuran setelah diberikan perlakuan. Hal ini dilakukan untuk mengetahui pengaruh perlakuan yang diberikan berupa pelatihan kelas "Tommoane Masayang" terhadap peningkatan pengetahuan dan 
keterampilan para suami. Penelitian ini dilaksanakan di Puskesmas Banggae 1 dan Puskesmas Totoli, dengan periode pengambilan data mulai Maret sampai September tahun 2020. Sampel yang digunakan adalah para suami ibu hamil dengan usia kehamilan 28-40 minggu kehamilan (Trimester ketiga kehamilan). Teknik pengambilan sampel, yaitu total sampling. Instrument penelitian yang digunakan, yaitu kuesioner karakteristik responden, kuesioner tentang kesehatan selama kehamilan dan lembar observasi untuk penilaian keterampilan. Selain itu, pada pelaksanaan pelatihan peneliti menggunakan media KIE, yaitu buku KIA (buku pink), leafleat, boneka bayi, dan perlengkapan bayi lainnya.

Pengumpulan data dilakukan dengan cara wawancara. Setelah responden menandatangani lembar inform consent, maka dilanjutkan dengan mengisi lembar kuesioner. Pada saat pre test, kuesioner diberikan pada para suami yang mengikuti pelatihan. Setelah selesai mengisi kuesioner akan dilanjutkan pelatihan dan keterampilan tentang kesehatan ibu hamil. Pengambilan data sebanyak dua kali, yaitu sebelum diberikan intervensi dan satu kali sesudah diberikan intervensi. Pengukuran setelah diberikan perlakuan sebanyak satu kali dengan selang waktu tiga hari dari pengukuran pertama ke pengukuran kedua. Waktu yang diberikan selama pengisian kuesioner baik sebelum maupun setelah perlakuan selama 30 menit. Penilaian keterampilan dicatat dalam lembar observasi. Setelah selesai, kuesioner dikumpulkan dan setiap keterampilan yang telah dilakukan dicatat dalam lembar observasi. Data yang telah terkumpul dilakukan analisis, meliputi: proses coding, editing, processing dan cleaning. Prinsip etik yang diterapkan yaitu Autonomy, Privacy, Beneficence dan Maleficence, serta prinsip Justice.

\section{HASIL}

Karakteristik responden pada table 1 berdasarkan umur menunjukkan bahwa dari 30 responden, umur terbanyak berada di rentang usia 21-30 tahun dengan jumlah responden 15 orang (50\%), dan umur paling sedikit berada di rentang usia 11-20 tahun dengan jumlah 2 orang (6.7\%). Karakteristik responden berdasarkan pekerjaan menunjukkan nelayan merupakan pekerjaan terbanyak dengan jumlah 18 orang (60.0\%), dan supir, honorer dan perawat merupakan pekerjaan yang paling sedikit dengan jumlah masingmasing 1 orang (3.3\%). Karakteristik responden berdasarkan pendidikan, terdapat 16 responden berpendidikan SD (53.3\%) dan 1 responden masih berstatus mahasiswa (3.3\%). Karakteristik responden berdasarkan jumlah kehamilan yaitu, jumlah kehamilan terbanyak berada di jumlah kehamilan 1 dengan jumlah 10 orang (33,3\%), dan paling sedikit berada di jumlah kehamilan 7 dan 11 dengan jumlah 1 orang $(3,3 \%)$.

Tabel 1. Distribusi karakteristik responden di Puskesmas Banggae 1 dan Puskesmas Totoli Kab. Majene Tahun 2020

\begin{tabular}{lcc}
\hline Karakteristik & Frekuensi & Persentase (\%) \\
\hline Umur & 2 & 6.7 \\
$11-20$ & 15 & 50.0 \\
$21-30$ & 10 & 33.3 \\
$31-40$ & 3 & 10.0 \\
$41-50$ & & \\
Pekerjaan & 5 & 16.7 \\
Wiraswasta & 1 & 3.3 \\
Honorer & 1 & 3.3 \\
Supir & 18 & 60.0 \\
Nelayan & 2 & 6.7 \\
Tukang batu & 1 & 3.3 \\
Perawat & 2 & 6.7 \\
Buruh & &
\end{tabular}




\begin{tabular}{lcc}
\hline Karakteristik & Frekuensi & Persentase (\%) \\
\hline Pendidikan & 16 & \\
SD & 3 & 53.3 \\
SMP & 6 & 10.0 \\
SMA/SMK & 1 & 20.0 \\
Mahasiswa & 2 & 3.3 \\
Tidak sekolah & 2 & 6.7 \\
S1 & & 6.7 \\
Jumlah kehamilan & 10 & \\
1 & 4 & 33.3 \\
2 & 3 & 13.3 \\
3 & 4 & 10.0 \\
4 & 4 & 13.3 \\
5 & 3 & 13.3 \\
6 & 1 & 10.0 \\
7 & 1 & 3.3 \\
11 & & 3.3 \\
\hline
\end{tabular}

Tabel 2 menunjukkan bahwa $P$ value $=0,031,<\alpha 0,05$, disimpulkan bahwa ada pengaruh kelas "Tommuane Masayang" terhadap pengetahuan para suami mengenai kesehatan ibu dan anak.

Tabel 2. Analisis pengaruh kelas "Tommoane Masayang" terhadap pengetahuan para suami mengenai kesehatan ibu dan anak di Puskesmas Banggae 1 dan Puskesmas Totoli Kab. Majene Tahun 2020

\begin{tabular}{|c|c|c|c|c|c|c|c|c|}
\hline & & \multicolumn{6}{|c|}{ Setelah Intervensi } & \multirow{3}{*}{ P value } \\
\hline \multicolumn{2}{|c|}{ Pengetahuan } & \multicolumn{2}{|c|}{ Baik } & \multicolumn{2}{|c|}{ Cukup } & \multicolumn{2}{|c|}{ Total } & \\
\hline & & $\mathbf{n}$ & $\%$ & $n$ & $\%$ & $\mathrm{n}$ & $\%$ & \\
\hline \multirow{3}{*}{$\begin{array}{l}\text { Sebelum } \\
\text { Intervensi }\end{array}$} & Baik & 22 & 73,3 & 0 & 0,0 & 22 & 73,3 & \multirow{3}{*}{$0,031^{*}$} \\
\hline & Cukup & 6 & 20,0 & 2 & 6,7 & 8 & 26,7 & \\
\hline & Total & 28 & 93,3 & 2 & 6,7 & 30 & 100 & \\
\hline
\end{tabular}

* Uji McNemar Test

Tabel 3 menunjukkan bahwa $P$ value $=0,001,<\alpha 0,05$, disimpulkan bahwa ada pengaruh kelas "Tommuane Masayang" terhadap keterampilan para suami mengenai kesehatan ibu dan anak.

Tabel 3. Analisis pengaruh kelas "Tommoane Masayang" terhadap keterampilan para suami mengenai kesehatan ibu dan anak di Puskesmas Banggae 1 dan Puskesmas Totoli Kab. Majene Tahun 2020

\begin{tabular}{|c|c|c|c|c|c|c|c|c|}
\hline \multirow{3}{*}{\multicolumn{2}{|c|}{ Keterampilan }} & \multicolumn{6}{|c|}{ Setelah Intervensi } & \multirow{3}{*}{$P$ value } \\
\hline & & \multicolumn{2}{|c|}{ Baik } & \multicolumn{2}{|c|}{ Kurang } & \multicolumn{2}{|c|}{ Total } & \\
\hline & & $\mathrm{n}$ & $\%$ & $\mathrm{n}$ & $\%$ & $\mathrm{n}$ & $\%$ & \\
\hline \multirow{3}{*}{$\begin{array}{l}\text { Sebelum } \\
\text { Intervensi }\end{array}$} & Baik & 13 & 43,3 & 0 & 0,0 & 13 & 43,3 & \multirow{3}{*}{$0,001^{*}$} \\
\hline & Kurang & 11 & 36,7 & 6 & 20,0 & 17 & 56,7 & \\
\hline & Total & 24 & 80,0 & 6 & 20,0 & 30 & 100 & \\
\hline
\end{tabular}

\footnotetext{
* Uji McNemar Test
} 


\section{PEMBAHASAN}

Hasil penelitian menunjukkan bahwa ada pengaruh kelas "Tommoane Masayang" terhadap peningkatan pengetahuan suami tentang kesehatan ibu dan anak. Menurut penelitian Simkin (2007), suami merupakan orang yang dianggap paling dekat dengan ibu, dan bertanggung jawab dalam segala hal terhadap sesuatu tentang ibu. Sehingga dalam setiap hal suami harus siap untuk selalu memberikan dukungan, nasihat dan mendampingi ibu dalam beberapa peristiwa yang akan dilalui ibu termasuk persalinan. Hal ini sejalan dengan penelitian yang menyatakan bahwa melibatkan anggota keluarga, khususnya pasangan (suami), membantu dalam meningkatkan sikap dan pengetahuan untuk mengurangi persalinan dengan operasi Caesar (Sharifirad, Razaeian, Soltani, Javaheri, \& Mazaheri, 2013).

Partisipasi suami dalam kesehatan reproduksi adalah tanggungjawab pria dalam kesehatan reproduksi terutama dalam pemeliharaan kesehatan dan kelangsungan hidup ibu dan anak, serta berperilaku seksual yang sehat dan aman bagi dirinya, istri dan keluarganya. Salah satu bentuk dari upaya pemeliharaan kesehatan reproduksi yaitu dengan keterlibatan suami dalam peningkatan pengetahuan dan keterampilan terkait kesehatan ibu dan anak. Hal ini berarti bahwa suami harus mencari informasi dan memberikan informasi tersebut kepada ibu. Hal ini ditunjukkan melalui partisipasi suami dalam mengikuti kelas "Tommoane Masayang". Peran suami tidak hanya sebagai pengambil keputusan, namun juga diharapkan selalu siaga dan memberikan perhatian terhadap kesehatan dan keselamatan ibu hamil. Dukungan suami melalui keikutsertaan suami dalam kelas ibu hamil sangat membantu dalam pembentukan perilaku kesehatan ibu.

Hal ini sejalan dengan penelitian Lestari, Susanti \& Fathunikmah (2018) dan Yusmaharani (2019) yang menunjukkan bahwa ada hubungan antara dukungan suami dengan pemanfaatan kelas ibu hamil. Dukungan suami sangat membantu dalam pembentukan perilaku kesehatan ibu karena ibu hamil akan cenderung menuruti apa yang disarankan oleh suaminya, sehingga dukungan sosial suami menjadi faktor yang besar hubungannya dengan keikutsertaan ibu dalam mengikuti kelas ibu hamil (Lestari, 2018). Menurut Sarafino \& Smith (2011) mengenai salah satu bentuk dukungan social yaitu dukungan dalam bentuk informasi. Melalui informasi yang diperoleh diharapkan dapat meningkatkan pengetahuan terkait kesehatan ibu dan anak. Corinne, Rogers, Suruchi (2010) menyatakan bahwa pengetahuan merupakan segala sesuatu yang diketahui berdasarkan pengalaman manusia itu sendiri dan pengetahun akan bertambah sesuai dengan proses pengalaman yang dialaminya.

Hasil penelitian ini juga menunjukkan bahwa ada pengaruh kelas "Tommoane Masayang" terhadap peningkatan keterampilan suami tentang kesehatan ibu dan anak. Keterampilan merupakan kepiawaian untuk melakukan pekerjaan secara mudah dan tepat. Peneliti berpendapat bahwa efek kelas "Tommoane Masayang" terhadap peningkatan keterampilan suami dikarenakan sebagian besar responden telah memiliki anak lebih dari satu (istri dalam kategori ibu multipara). Selain itu, keterampilan suami dapat dipengaruhi oleh berbagai factor, salah satunya adalah pengalaman. Pengalaman akan mempengaruhi keterampilan karena dengan adanya pengalaman akan meningkatkan kepercayaan diri suami dalam dalam hal melakukan perawatan pada bayi baru lahir (Yulianisa dan Mardiyah, 2019).

Keterampilan suami dalam penelitian ini, yaitu melakukan perawatan pada bayi baru lahir antara lain memandikan bayi, mengganti popok bayi dan cara menggendong bayi yang baik dan benar. Keterampilan ini diajarkan pada saat suami mengikuti kelas "Tommoane Masayang". Sesuai teori bahwa keterampilan diajarkan dengan menggambarkan keterampilan, mempertunjukkan keterampilan, dan memberikan kesempatan setiap individu untuk mempraktikkan keterampilan tersebut. 
Penelitian ini sejalan dengan penelitian Yulianisa dan Mardiyah (2019) menyatakan bahwa ada hubungan keterampilan individu dengan perilaku pencegahan infeksi luka perineum. Penelitian lain juga menunjukkan ada peningkatan keterampilan ibu tentang menyusui yang benar pada kelompok konseling pasutri (Prihastuti, 2014). Peningkatan keterampilan juga dapat disebabkan oleh pengalaman yang dimiliki responden (Notoatmodjo, 2010). Pengalaman berkaitan erat dengan aktivitas sehari - hari dan pekerjaan seseorang. Di mana sebanyak 20 responden merupakan suami yang telah memiliki anak lebih dari satu. Sehingga ketika responden sudah memperoleh pengetahuan, bukan menjadi hal yang sulit untuk mempraktikkan bagaimana menajdi seorang suami siaga. Hal ini menunjukkan bahwa keterlibatan suami dalam pemeliharaan kesehatan ibu dan anak sangat berpengaruh.

Hasil penelitian ini menunjukkan bahwa kelas "tommoane masayang" dapat meningkatkan pengetahuan dan keterampilan suami tentang kesehatan ibu dan anak. Penelitian ini sejalan dengan penelitian Ariyani, Mindarti, \& Nuh (2016), yaitu melalui gerakan suami siaga dapat dijadikan sebuah inovasi metode pelayanan yang terdiri atas pembekalan, pelaksanaan, dan evaluasi hasil pelatihan. Hasil penelitian ini juga didukung oleh penelitian sebelumnya tentang pengaruh kampanye "Suami Siaga" di Indonesia pada tahun 1999-2000 sebagai salah satu intervensi yang ditujukan pada para suami tentang kesiapsiagaan menjelang persalinan. Ada efek dari kampanye tersebut antara lain, suami memperoleh pengetahuan baru tentang kesiapan menjelang persalinan dan tindakan suami untuk menjadi suami siaga (Shefner, Rogers \& Sood, 2010). PEnetapan suami sebagai salah satu fokus dalam program pendidikan kesehatan ibu dapat menciptakan perilaku yang dapat meningkatkan kesehatan ibu (Renata, Masfiah \& Gamelia, 2015).

\section{SIMPULAN DAN SARAN}

Ada pengaruh kelas "Tommuane Masayang" terhadap peningkatan pengetahuan dan keterampilan para suami mengenai kesehatan ibu dan anak di Puskesmas Banggae 1 dan Puskesmas Totoli Kabupaten Majene tahun 2020. Dalam upaya peningkatan pengetahuan dan keterampilan suami dalam keterlibatan suami selama masa kehamilan istri sampai persalinan, dibutuhkan dukungan dari petugas kesehatan. Saran dari peneliti, setiap pelaksanaan kelas ibu hamil agar melibatkan suami, karena suami memiliki peran yang penting dalam menjaga kesehatan ibu dan anak.

\section{DAFTAR PUSTAKA}

Ariyani, a., Mindarti, L.I., \& Nuh, M. (2016). Inovasi Pelayanan Publik (Studi pada Pelayanan Kesehatan melalui Program Gebrakan Suami Siaga di Puskesmas Gucialit Kabupaten Lumajang). Jurnal Ilmiah Administrasi Publik (JIAP), 2(4), 156-161.

Corinne, L.S., Rogers., Suruchi, S. (2010). Involving husbands in safe motherhood: effect of the SUAMI SIAGA campaign in Indonesia. Journal of Health Communication, 9(3). https://doi.org/10.1080/10810730490447075.

Gholamreza, S., Mohsen, R., Raheleh, S., Somayeh, J., Mazaheri, M. A. (2013). A Survey on the effect of husbands education of pregnant women on knowledge, attitude, and reducing elective cesarean section. J Educ Health Promot. DOI : 10.4103/2277-9531.119036.

Kementerian Kesehatan Republik Indonesia. (2018). Profil Kesehatan Indonesia Tahun 2017. Jakarta: Kemenkes RI. 
Kementerian Kesehatan Republik Indonesia. (2018). Riset Kesehatan Dasar. Bakti Husada: Badan Penelitian Dan Pengembangan Kesehatan

Kementerian Kesehatan Republik Indonesia. (2017). Pedoman Pelaksanaan Kelas Ibu Hamil. Jakarta: Kemenkes RI.

Lestari, T.A., Susanti, A., \& Fathunikmah. (2018). Faktor-Faktor yang Berhubungan dengan Keikutsertaan Ibu Hamil dalam Mengikuti Kelas Ibu Hamil di Wilayah Kerja Puskesmas Kampar Kiri Tangah Kabupaten Kampar. Jurnal Ibu dan Anak, 6(2), 112-119.

Notoatmodjo, S. (2010). Promosi Kesehatan Teori dan Aplikasi. Rineka Cipta. Jakarta

Prihastuti. (2014). Pengaruh Konseling Menyusui kepada Pasturi terhadap pengetahuan, Dukungan dan Keterampilan Teknik menyusui. Jurnal Ilmu Kebidanan, 2(1).

Renata, D.S., Masfiah, S., Gamelia, E. (2015). Efektivitas Pelatihan Tokoh Masyarakat sebagai Peer Edukator Suami Siaga dalam Perawatan Kehamilan Istri di Wilayah Kerja Puskesmas I Ajibarang. Jurnal IImiah Kesehatan Masyarakat, 7(3), 167-178.

Sarafino, E. P., \& Smith, T. W. (2011). Biopsychological Interactions. New York: Health Psychology

Sharifirad, G., Rezaeian, M., Soltani, R., Javaheri, S., \& Mazaheri, M. A. (2013). A survey on the effects of husbands' education of pregnant women on knowledge, attitude, and reducing elective cesarean section. Journal of education and health promotion, 2, 50. https://doi.org/10.4103/22779531.119036

Simkin., P. (2007). Panduan Lengkap Kehamilan, Melahirkan, dan Bayi. Jakarta: Arcan.

The World Bank. (2019). Maternal Mortality Ratio (modeled estimate, per 100.000 live births)-Indonesia. https://data.worldbank.org/indicator/SH.STA.MMRT?locations=ID.

Yulianisa, E \& Mardiyah, M.S. (2019). Sikap, Keterampilan Individu dan Dukungan Suami terhadap Perilaku Pencegahan Infeksi Luka Perineum Ibu Postpartum. Jurnal IImiah Kebidanan Indonesia, 9(4). 154162. https://doi.org/10.33221/jiki.v9i04.409

Yusmaharani, Y. (2019). Hubungan Dukungan Suami dengan Pemanfaatan Kelas Ibu hamil. Jurnal Kesmas Asclepius, 1(2), 86-95. https://doi.org/10.31539/jka.v1i2.586. 